\title{
Preparation, characterization and biological evaluation of chitosan- moxifloxacin prodrugs for pharmaceuticals
}

\author{
Alok Semwal1, Singh Ramandeep 1
}

\begin{abstract}
OBJECTIVE: In recent years, excipient development has become major area of research in pharmaceutical drug delivery because it influences the formulation development and drug delivery process in various ways. In modern pharmaceutical science biopolymers are choice of research as excipient because of their low toxicity, biocompatibility, biodegrability, stability and renewable nature. Chitosan, a biodegradable polysaccharide derived from chitin and found widely in nature, possesses properties making it particularly suitable as a carrier, including its high viscosity, charge distribution and release mechanisms. Our present research work includes preparation and characterization of chitosan-moxifloxacin conjugates designed in accordance with specific biomedical requirements.
\end{abstract}

METHODS: In this research work chitosan based chitosan-moxifloxacin conjugates have been successfully formulated by using distilled water and glacial acetic acid mixture and the film was made by solution casting method. Formulated films were characterized by various analytical methods such as UV, IR and DSC as well as biological methods.

RESULTS: The antibacterial activity of chitosan-moxifloxacin conjugates was tested against various microorganisms viz, gram positive bacteria's Streptococcus pneumoniae and Staphylococcus aureus and the results indicated that the antibacterial activity of chitosan-moxifloxacin conjugates was several time greater than that of parent drug moxifloxacin. This may be due to the favorable pharmacokinetics, pharmacodynamics, excellent bacterial susceptibility and good stability of the drug conjugates.

CONCLUSION: This proposed combination may result in the enhancement of the separate activities of chitosan and moxifloxacin.

KEYWORDS: MFX (Moxifloxacin), CH (Chitosan), conjugate, prodrug, electrostaticinteraction, antimicrobial etc.

\section{INTRODUCTION}

MFX is a fourth-generation synthetic fluoroquinolone derivative which has broad antimicrobial activity and is effective after oral administration for the treatment of a wide variety of infectious diseases. MFX, a fluoroquinolone, is available as the monohydrochloride salt of 1-cyclopropyl-6-fluoro-8-methoxy-7-((4aS,7aS)-octahy- dropyrrolo [3,4-b]pyridin-6-yl)-4-oxo-1,4-dihydro quinoline-3-carboxylic acid. It is a slightly yellow to yellow crystalline substance with a molecular weight of 437.9. Its empirical formula is $\mathrm{C}_{21} \mathrm{H}_{24} \mathrm{FN}_{3} \mathrm{O}_{4} \cdot \mathrm{HCl}$ (1). It is marketed worldwide (as the Moxifloxacin hydrochloride) under the brand names Avelox, Avalox, and Avelon. In most countries, the drug is also available in par-
AFFILIATIONS

1Department of Pharmacy,

Himachal Institute of

Pharmacy, Paonta Sahib,

(H.P), India

CORRESPONDENCE

Alok Semwal

E-mail:

alokm.pharm01@gmail.com

Received:

03.11.2013

Revision:

17.12.2013

Accepted:

18.12.2013 
enteral form for intravenous infusion. MFX is also sold in an ophthalmic solution (eye drops) under the brand names Vigamox, Moxeza for the treatment of conjunctivitis (pink eye) (2). The quinolone antibiotics target bacterial DNA gyrase and topoisomerase IV (3). For many gram-positive bacteria (such as $S$. aureus), topoisomerase IV is the primary activity inhibited by the quinolones. In contrast, for many gram-negative bacteria (such as E. coli), DNA gyrase is the primary quinolone target (4). MFX is a broad-spectrum antibiotic that is active against both gram-positive and gram-negative bacteria. It functions by inhibiting DNA gyrase, a type II topoisomerase, and topoisomerase IV (3), enzymes necessary to separate bacterial DNA, thereby inhibiting cell replication.

Despite much progress in the field of antibacterial drug discovery, antibacterial drugs in current clinical use generally suffer from a series of deficiencies, including excessive organ toxicity, lack of specificity, short circulation half-lives, and a pronounced tendency to induce resistance in the target cells.

Polymer systems for drug release have been widely used in medicine, since they enable the slow and gradual release of the active ingredient, with better targeting within the body, such as towards areas of inflammation or tumors. $\mathrm{CH}$, a biodegradable polysaccharide derived from chitin and found widely in nature, possesses properties making it particularly suitable as a carrier, including its high viscosity, charge distribution and release mechanisms. Research into the chemical properties of $\mathrm{CH}$ has demonstrated its suitability for the preparation of enzymatic biosensors for the analysis of metallic elements, proteins and lipids. Pharmaceuticals possessing antibiotic properties have been explored as good candidates for the preparation of formulations based on polymeric controlled release systems. Carrier materials such as $\mathrm{CH}$ have been employed to protect the pharmaceutical agent so that it may be released under optimal absorption conditions, or to adjust the timing of release of different pharmaceutical agents administered simultaneously. The potential application of $\mathrm{CH}$ is hindered by its limited solubility in aqueous media (5). $\mathrm{CH}$ is a biopolymer which is well tolerated (biocompatible); it also approved to be an efficient carrier for the controlled delivery of drugs. It is well known that $\mathrm{CH}$ from the ocean resources has been found wide application in various areas as a result of its biocompatibility and nontoxicity, especially in the pharmaceutical and biomedical fields, such as drug delivery (6-9), wound dressing $(10,11)$ food packing $(12)$, Tissue engineering (13) and antimicrobial agents (14-15). " $\mathrm{CH}$ has one primary amino and two free hydroxyl groups for each $\mathrm{C}_{6}$ building unit. Due to the easy availability of free amino groups in $\mathrm{CH}$, it carries a positive charge and thus in turn reacts with many negatively charged polymers or substances" (16). CH is a weak base and is insoluble in water and organic solvents, however, it is soluble in dilute aqueous acidic solution ( $\mathrm{pH}$ 6.5), which can convert the glucosamine units into a soluble form $\mathrm{R}-\mathrm{NH}_{3}{ }^{+}(17)$. It gets precipitated in alkaline solution or with polyanions and forms gel at lower $\mathrm{pH}$. It has been reported that multilayer beads of $\mathrm{CH}$-antibiotic complex showed improved properties for controlled delivery of the antibiotics (18). Besides this several attempts have been made in order to improve the therapeutic efficacy of antibiotics which involves successful use of $\mathrm{CH}$.
In this work the degree of interaction between $\mathrm{CH}$ and MFX is investigated using various analytical techniques, envisaging possible applications in new formulations based on optimization of the therapeutic dose in order to improve the quality of life of patients.

\section{Experimental section}

\section{Material and methods}

$\mathrm{CH}$ with $79 \%$ degree of deacetylation (DD) was sponsored by Central Institute of Fisheries Technology (CIFT, Cochin, India). MFX was received as a gift sample from Cosmas Pharmaceuticals Pvt. Ltd. Vill. Kotla Solan Baddi, India. The bacterial test strains Streptococcus pneumoniae and Staphylococcus aureus were purchased from IMTECH, Chandigarh, India. All materials, solvents and solutions were of analytical grade.

\section{Preparation of chitosan-moxifloxacin conjugates}

\section{(i). Preparation of chitosan solution}

$\mathrm{CH}$ is a weak base which is insoluble in water and other organic solvents however, it has a unique property to become soluble in dilute aqueous acidic solution. To synthesize $\mathrm{CH}-\mathrm{MFX}$ conjugates, $1 \% \mathrm{CH}$ solution was prepared with the help of glacial acetic acid $(1 \% \mathrm{w} / \mathrm{v})$ and distilled water.

The following mixture of $\mathrm{CH}$ was kept at room temperature $\left(20^{\circ} \mathrm{C}\right)$ for 24 hours with continuous stirring. The mixture was stirred magnetically until the polymer was completely dissolved and a viscous solution is formed. The solution was filtered through glass-wool to remove undissolved particles of $\mathrm{CH}$.

\section{(ii). Preparation of drug solution}

MFX is completely soluble in aqueous solvents. To prepare the drug solution about 200mg of MFX drug was dissolved in minimum amount of distilled water; the solution was stirred until a homogenous mixture is formed.

\section{(iii). Drug loading}

MFX solution was gradually added to the above solution over 2 min with continuous stirring. The mixture was then stirred for further 24 hours at room temperature $\left(20^{\circ} \mathrm{C}\right)$. To concentrate the resulting solution, it was kept for $48 \mathrm{hrs}$ in an incubator at $37^{\circ} \mathrm{C}$. A highly viscous solution was obtained which was then successfully used for further process.

\section{(iv). Preparation of films}

$\mathrm{CH}-\mathrm{MFX}$ prodrug conjugate was prepared by solution casting method (19). Films were prepared by pouring and spreading the CH-MFX mixture on a glass plate, and kept in microwave oven for 30 minutes at $37^{\circ} \mathrm{C}$. After microwave treatment the resulting film was kept at room temperature $\left(20^{\circ} \mathrm{C}\right)$. After two days films were collected and used for further characterization and antibacterial activity.

\section{Measurements/characterization techniques}

\section{UV-Vis spectroscopy}

$\mathrm{UV} / \mathrm{Vis}$ spectroscopy is routinely used in the quantitative determination of solutions of transition metal ions highly conjugated organic compounds, and biological macromolecules. Organic compounds, especially those with a high degree of conjugation, also absorb light in the UV or visible regions of the electromagnetic spectrum. UV-Vis spectra of the films were scanned in the wavelength range 200-800 nm using UVVis spectrophotometer (1800 PC UV spectrometer, Shimadzu). 
Fourier Transform Infrared Spectroscopy (FTIR)

The infrared spectra were recorded using FTIR spectrophotometer with attenuated total reflection technique for investigation of intermolecular interactions. The CH-MFX conjugate film was taken and infrared data were collected between 500$4000 \mathrm{~cm}^{-1}$.

\section{Differential Scanning Calorimetry (DSC)}

DSC is used widely for examining polymeric materials to determine their thermal transitions. The observed thermal transitions can be utilized to compare materials, however, the transitions do not uniquely identify composition. The percent crystalline content of a polymer can be estimated from the crystallization/melting peaks of the DSC graph as reference heats of fusion can be found in the literature (20). In the pharmaceutical field it is necessary to have well-characterized drug compounds in order to define processing parameters. For instance, if it is necessary to deliver a drug in the amorphous form, it is desirable to process the drug at temperatures below those at which crystallization can occur (21).

In this research work differential scanning calorimetry was used to examine the thermal property of CH-MFX conjugate with a constant heating rate of $10^{\circ} \mathrm{C} /$ min under a nitrogen flow in thermetically sealed aluminium pans. The weight of sample ranged between 2-3 $\mathrm{mg}$. The results were recorded and analyzed.

\section{Swelling test}

In order to check the swelling ability of the MFX loaded $\mathrm{CH}$ conjugates (CH-MFX films) 50 ML phosphate buffer solution of $\mathrm{pH} 7.4$ was used. Phosphate buffer of required $\mathrm{pH}$ was prepared by Dissolving $2.38 \mathrm{~g}$ of disodium hydrogen phosphate, $0.19 \mathrm{~g}$ of potassium dihydrogen phosphate and $8.0 \mathrm{~g}$ of sodium chloride in sufficient water to produce $1000 \mathrm{ml}$. $\mathrm{pH}$ of the buffer solution was adjusted to 7.4. The CH-MFX films $(1.5 \times 1.5$ $\mathrm{cm}^{2}$ ) were placed in $50 \mathrm{ml}$ of phosphate buffer solution and incubated at $37^{\circ} \mathrm{C}$. At the time intervals of 2, 4, 6 and 8 hours, the films were taken out and excess water was removed from the film carefully using filter paper and films were weighed immediately (22).

Percentage swelling of CH-MFX prodrug at equilibrium was calculated from the following formula.

$$
\mathrm{DS}=(\mathrm{Ww}-\mathrm{Wd}) / \mathrm{Wd}
$$

Where, $W w$ and $W d$ are weights of wet and dry film respectively.

\section{Antimicrobial activity tests and biological relevance (22)}

Microbiological efficiency of antimicrobial CH-MFX conjugates and conjugates forming solution were evaluated by using agar diffusion method.

\section{Preparation of microorganisms}

Bacteria was cultured in nutrient broth and incubated overnight at $37^{\circ} \mathrm{C}$ for $24 \mathrm{hrs}$. The bacterial cultures obtained were diluted with autoclaved nutrient. This culture served as the inoculums for the antimicrobial experiments.
Preparation of agar plates for antimicrobial activity nutrient agar plates were prepared by mixing nutrient agar (28 gm) in $1000 \mathrm{ml}$ distilled water boiled to dissolve the medium completely. Nutrient agar solution was sterilized by autoclaving at $121^{\circ} \mathrm{C}$ for $15 \mathrm{~min}$ at $15 \mathrm{lb}$ pressure. After cooling $\left(45^{\circ} \mathrm{C}\right)$, agar solution $(25 \mathrm{ml})$ were poured into sterilized petri dishes and left to solidify. Agar plates were inoculated with an overnight bacterial culture, using spread plate method after appropriate serial dilutions. Nutrient agar plates were used for Streptococcus pneumoniae and Staphylococcus aureus. The antimicrobial CH-MFX based conjugates forming solution was aseptically put into the wells $(100 \mu \mathrm{l}$ approx) made in agar plates making lawns of different test cultures. The nutrient agar plates were then incubated at 37 ${ }^{\circ} \mathrm{C}$ for $24 \mathrm{hrs}$. The diameter of inhibitory zone surrounding film disc and antimicrobial $\mathrm{CH}$ based conjugate forming solution was then measured after 24 hrs. Two cross sectional points and the average was taken as the inhibition zone and the size of the zone diameter was measured. The plates were then photographed individually.

The inhibition zone diameter of the MFX was compared with the zone diameter of $\mathrm{CH}-\mathrm{MFX}$ conjugate.

\section{RESULTS AND DISCUSSION}

\section{Proposed reaction scheme}

When MFX drug added to the $\mathrm{CH}$ solution, in the presence of glacial acetic acid, the acidic group (-COOH) of MFX converts into anion $\mathrm{COO}^{-}$and amine $\left(-\mathrm{NH}_{2}\right)$ group of $\mathrm{CH}$ converts into cation $\mathrm{NH}_{3}{ }^{+}$. CH-MFX complex forms due to the electrostatic interaction between $\mathrm{NH}_{2}$ group of $\mathrm{CH}$ and $\mathrm{COOH}$ group of MFX drug [Reaction Scheme 1]. Furthermore the prepared complex was characterized by various analytical methods.

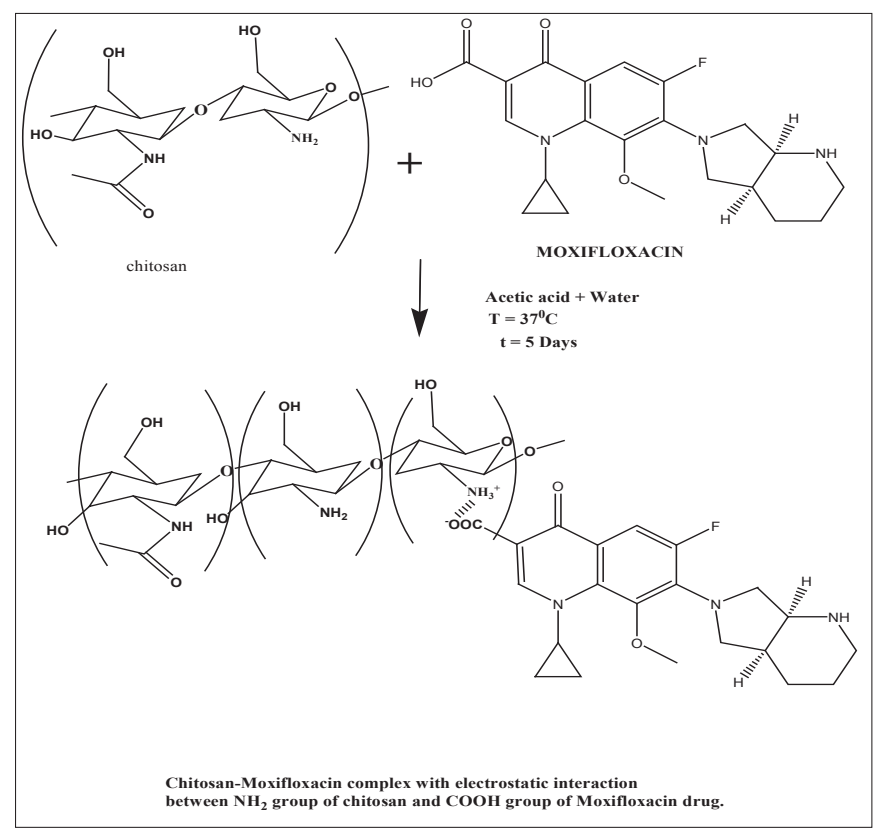

REACTION SCHEME 1. Preparation of CH-MFX complex 


\section{Characterization}

\section{Ultra violet spectroscopy}

Because of its transparency it's hard to characterize $\mathrm{CH}$ by UV spectroscopy methods. However, we can overcome this natural handicap by borrowing chromophores from extrinsic molecule. The acid group moieties play the role of reporter molecules for the spectroscopy study, from which the structural and antibacterial activity is, deduced (19).

UV spectra for all the synthesized compounds were recorded, and are included in the appendix. $\mathrm{CH}$ solution does not give any sharp peak in its UV spectrum, however a low intensity peak is observed at $278 \mathrm{~nm}$ (Figure 1(a)). MFX in aqueous medium showed characteristic absorption band around 285.50 nm (Figure 1(b)), where UV spectrum band of CH-MFX complex showed absorption at $286 \mathrm{~nm}$ (Figure 1(c)).

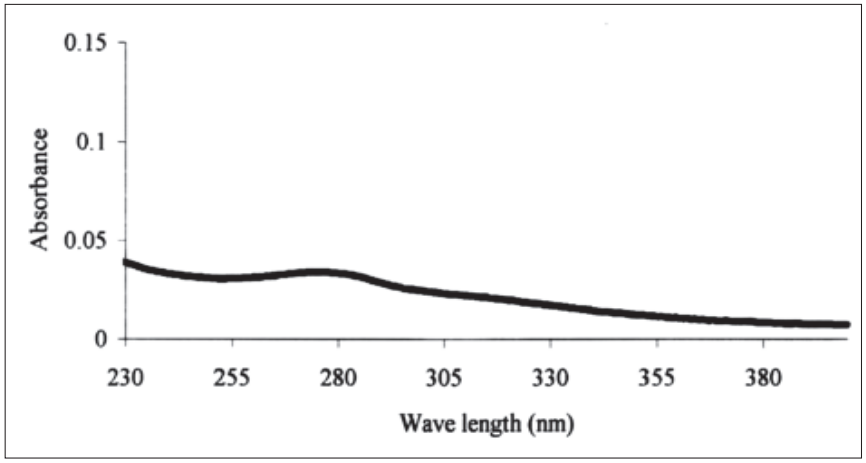

FIGURE 1 (a). UV Spectrum of pure $\mathrm{CH}$ in dil. glacial acetic acid

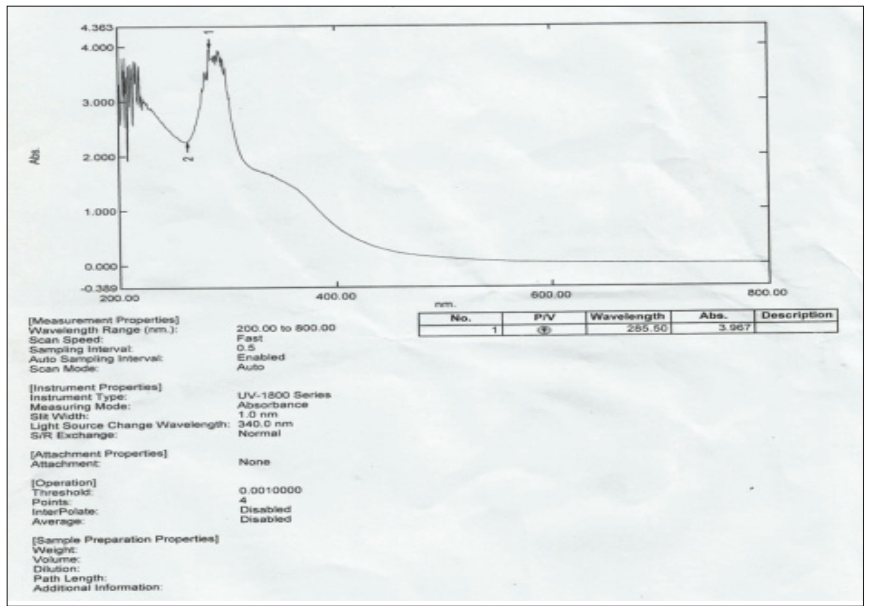

FIGURE 1(B). UV Spectrum of MFX in distilled water acid

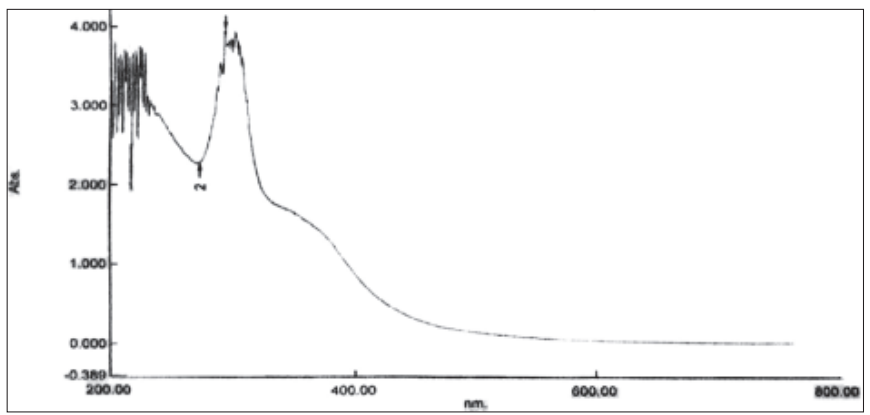

FIGURE 1(C). UV Spectrum of $\mathrm{CH}-\mathrm{MFX}$ complex in $1 \% \mathrm{v} / \mathrm{V}$ glacial acetic acid
Fourier Transform Infrared Spectroscopy (FTIR)

The FT-IR spectra for all the prepared compounds were recorded, and are included in the appendix. For $\mathrm{CH}$ spectrum (Figure.2 (a)): $3422 \mathrm{~cm}^{-1}$ (which is assigned to the N-H and hydrogen bonded $\mathrm{O}-\mathrm{H}$ stretch vibrational frequencies), while a sharp (shoulder) peak at $3610 \mathrm{~cm}^{-1}$ is that of free $\mathrm{O}-\mathrm{H}$ bond stretch of glucopyranose units, 2921 and $2867 \mathrm{~cm}^{-1}$ (C-H stretch), $2364 \mathrm{~cm}^{-1}$ (C-N asymmetric band stretching), 1653 $\mathrm{cm}^{-1}$ (amide II band, C-O stretch of acetyl group), $1592 \mathrm{~cm}^{-1}$ (amide II band, N-H stretch) $1375 \mathrm{~cm}^{-1}$ (asymmetric C-H bending of $\mathrm{CH}_{2}$ group) and $1071 \mathrm{~cm}^{-1}$ (skeletal vibration involving the bridge C-O stretch) of glucosamine residue.

For CH-MFX complex (Figure 2 (b)): the spectral band appear at $3422 \mathrm{~cm}^{-1}$ (axial $\mathrm{O}-\mathrm{H}$ group of $\mathrm{CH}$ ), Absorption arising from $\mathrm{C}-\mathrm{H}$ stretching in the alkanes occurs in the general region of $2949 \mathrm{~cm}^{-1}-2840 \mathrm{~cm}^{-1}$ (symmetric or asymmetric $\mathrm{CH}_{3}$ stretching vibration attributed to $\mathrm{MFX}$ and pyranose ring of $\mathrm{CH}$ ). A band at $2344 \mathrm{~cm}^{-1}$ refers to $\mathrm{C}-\mathrm{N}$ asymmetric band stretching, A broad, strong $\mathrm{NH}_{3}$ stretching band in the $3100-2600 \mathrm{~cm}^{-1}$ region and multiple combination and overtone bands extend the absorption to about $2000 \mathrm{~cm}^{-1}$, this overtone region usually contains a prominent band near 2222-2000 $\mathrm{cm}^{-1}$ (bending vibration and torsional oscillation of amine salt $\mathrm{NH}_{3}{ }^{+}$). One more fairly strong symmetric bending near $1562 \mathrm{~cm}^{-1}$ is the characterstic of $\mathrm{NH}_{3}{ }^{+}$absorption. A strong absorption of carboxylate ion occurred at $1413 \mathrm{~cm}^{-1}$, while a week absorption at around $1400 \mathrm{~cm}^{-1}$. 1400-1032 $\mathrm{cm}^{-1}$ (C-F band stretching of MFX), 943-623 $\mathrm{cm}^{-1}$ (mono and di-substituted benzene ring).

When IR spectrum of $\mathrm{CH}-\mathrm{MFX}$ compared with $\mathrm{CH}$ it showed purely electrostatic nature of the interaction between $\mathrm{CH}$ $\left(\mathrm{NH}_{3}{ }^{+}\right)$and MFX (COO-) is the new signals at 1562 and 1413 $\mathrm{cm}^{-1}$. This result suggested that the $\mathrm{NH}_{2}$ group on $\mathrm{CH}$ chains were protonated by the $\mathrm{H}^{+}$supplied while the carboxylic group of MFX is deprotonated.

The intensity of these bands totally depends on the concentration, type and bulkiness of the acid.

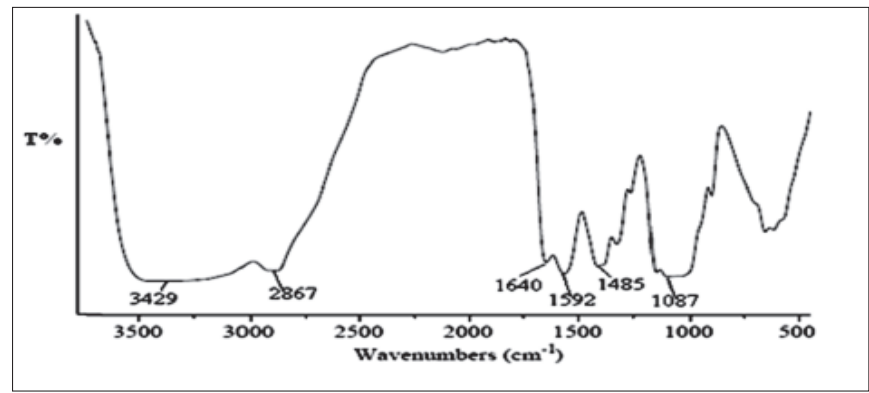

FIGURE 2 (A). Infrared spectrum of $\mathrm{CH}$

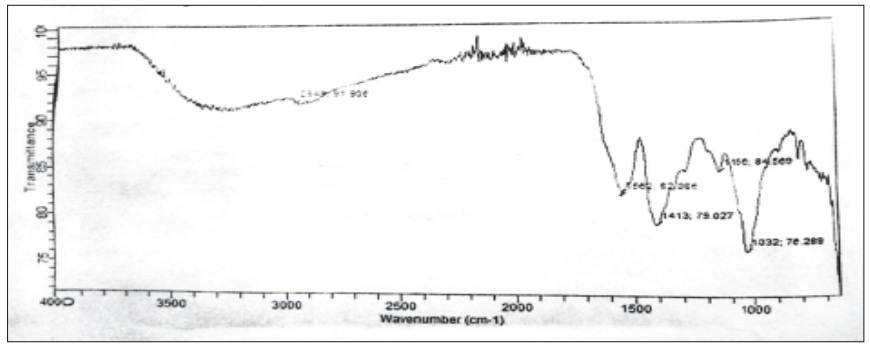

FIGURE 2(B). Infrared spectrum of CH-MFX complex 


\section{Differential Scanning Calorimetry (DSC)}

The DSC thermograms for $\mathrm{CH}$ and $\mathrm{CH}-\mathrm{MFX}$ complex were recorded, and are included in the Figure 3 (a), (b). CH showed two broad endothermic peaks at $92.3{ }^{\circ} \mathrm{C}$ and $212{ }^{\circ} \mathrm{C}$. The former peak may be due to the water vapor present in $\mathrm{CH}$ while the latter may be attributed to the molecular arrangement of $\mathrm{CH}$ chains. The $\mathrm{CH}-\mathrm{MFX}$ complex exhibit a sharp endothermic peak at $120^{\circ} \mathrm{C}$ due to structural arrangement and its degree of substitutional changes in the polysaccharide. There is a sharp exothermic peak at $238^{\circ} \mathrm{C}$ is due to the thermal decomposition of MFX. The results indicated that the structure of $\mathrm{CH}$ chains have been modified due to the introduction of MFX unit.

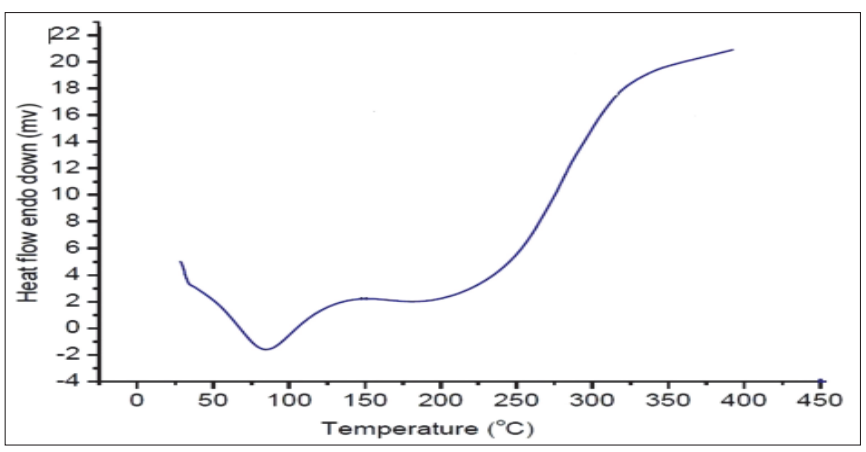

FIGURE 3(A). DSC thermograph of $\mathrm{CH}$

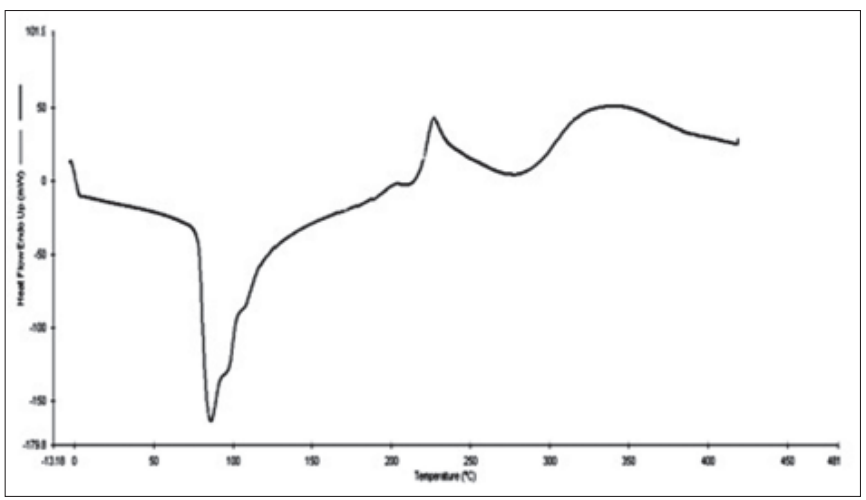

FIGURE 3(B). DSC thermograph of CH-MFX complex

\section{Swelling test}

It is well known that the sample with the highest degree of swelling will have the highest surface area/volume ratio. The hydrophilic nature of $\mathrm{CH}$ material may be a major factor that influences the extent of swelling in the formulations (CH-MFX).

The calculated equilibrium swelling ratio for prepared $\mathrm{CH}$ MFX complex is $1330 \%$. Swelling ratio of CH-MFX complex is demonstrated in Graph 1.

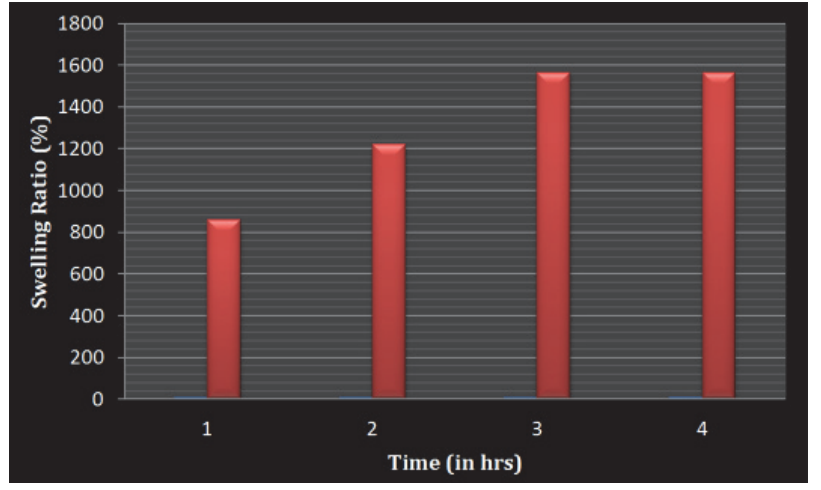

GRAPH 1. Swelling ratio of $\mathrm{CH}-\mathrm{MFX}$ complex films in phosphate buffer solution of $\mathrm{pH} 7.4$

Antimicrobial activity tests and biological relevance

Antibacterial activity of the CH-MFX complex film and its solution against Streptococcus pneumoniae and Staphylococcus aureus were measured by agar diffusion method. After $24 \mathrm{hrs}$ incubation at $37^{\circ} \mathrm{C}$, the $\mathrm{CH}-\mathrm{MFX}$ complex film and its solutions showed effective antibacterial effect on gram positive bacteria's Streptococcus pneumoniae and Staphylococcus aureus. The ability of the films and its solutions to inhibit growth of the tested strains is listed in Table 1 . The inhibitory activity was measured based on the diameter of the clear inhibition zone. In terms surrounding clearing zone, they both showed a very clear inhibitory effect against gram positive bacteria. Control (acetic acid, $0.1 \% \mathrm{v} / \mathrm{v}$ ) yielded no antimicrobial activity against all tested microorganisms. From the comparative study in between drug and complex it is clearly evident that $\mathrm{CH}-\mathrm{MFX}$ complex is more effective than MFX drug (Graph 2).

The present investigation therefore indicates that the complexes were effective for inactivating bacteria with the enhancement in the total activity. This is possibly due to the synergistic effect of both the $\mathrm{CH}$ and MFX in the composite. The results suggest that the antimicrobial activity of MFX can be enhanced by its conjugation with the $\mathrm{CH}$ in the form of films.

TABLE 1. Antibacterial activity of MFX and CH-MFX complex

\begin{tabular}{lccc}
\hline & \multicolumn{2}{c}{$\begin{array}{c}\text { Diameter }(\mathbf{m m}) \text { of inhibitory zone in aq. Acetic } \\
\text { acid }(\mathbf{0 . 1 \%}) \text { solution of the control }\end{array}$} \\
\cline { 2 - 4 } Test cultures & $\begin{array}{c}\text { MFX } \\
\text { (Drug) }\end{array}$ & $\begin{array}{c}\text { CH-MFX } \\
\text { Complex }\end{array}$ & $\begin{array}{c}\text { aq. Acetic acid (0.1\%) } \\
\text { solution (control) }\end{array}$ \\
\hline $\begin{array}{l}\text { Gram positive } \\
\text { (a). S. aureus }\end{array}$ & 25 & 27 & 00 \\
(b). S. pneumoniae & 21.3 & 23.1 & 00
\end{tabular}

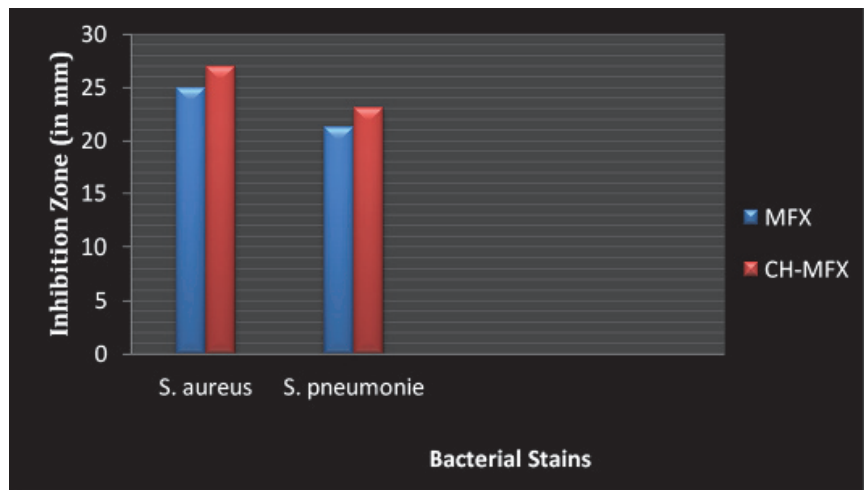

GRAPH 2. Comparative antibacterial study of MFX and $\mathrm{CH}-\mathrm{MFX}$ complex forming solution 


\section{SUMMARY AND CONCLUSION}

$\mathrm{CH}-\mathrm{MFX}$ prodrug conjugates have been successfully synthesized by using distilled water and glacial acetic acid mixture and the film was made by solution casting method. $\mathrm{CH}$ is soluble only in acidic medium, where in the alkaline medium it is usually precipitated out. Glacial acetic acid is a week acid which is used to maintain the acidic $\mathrm{pH}$ of the entire solution so that a homogeneous mixture can be prepared.

$\mathrm{CH}$ makes the films more flexible and allows the film wall to enlarge its surface and to swell to compensate for osmotic differences between interior and exterior of the films. The Fourier transform spectrum of the films showed that CH-MFX conjugate exhibits an interaction between $\mathrm{NH}_{2}$ group of $\mathrm{CH}$ and $\mathrm{COO}^{-}$group of MFX, which is a type of electrostatic interaction. Intermolecular bonding of electrostatic type forms a stronger bond because of the stronger attraction forces in between opposite ions. These biocompatible conjugate systems ( $\mathrm{CH}-\mathrm{MFX})$ can bypass the acidity of gastric fluid without liberating substantial amounts of the loaded compound. The above findings open new prospects and promise a quality material which undoubtedly widens the scope of application of chitosan based material in pharmaceuticals applications.

\section{Farmasötikler için kitozan moksifloksazin ön ilaçlarının hazırlanması, karakterizasyonu ve biyolojik olarak değerlendirilmesi}

\section{ÖZET}

AMAÇ: Son yıllarda, yardımcı maddelerle ilgili çalışmalar formülasyon geliştirilmesi ve ilaç salım prosesini çeşitli yollardan dolayı etkilediğinden farmasötik ilaç salım sistemlerinin başlıca araştırma alanlarından biri olmuştur. Modern farmasötik bilimlerde biyopolimerler düşük toksisite, biyolojik olarak geçimlilik, biyolojik olarak parçalanabilirlik, stabilite ve yenilenebilir yapılarından dolayı yardımcı madde olarak araştırmalarda bir seçenek olmuştur. Kitinden elde edilen, biyolojik olarak parçalanma özelliğine sahip ve doğada yaygın olarak bulunan kitozanın, yüksek viskozite, yük dağııımı ve salım mekanizması gibi özelliklere sahip olması onu uygun bir taşıyıcı sistem haline getirmiştir. Bu araştırma çalışması spesifik biyomedikal intiyaçlar doğrultusunda tasarlanan kitozan-moksifloksazin konjugatlarının hazırlanmasını ve karakterizasyonunu içermektedir.

METOD: Bu çalışmada distile su ve glasiyal asetik asit karışımı kullanılarak kitozan-moksifloksazin konjugatları başarılı olarak formüle edilmiş ve çözelti şekillendirme yöntemi ile film oluşturulmuştur. Oluşan filmler UV, IR ve DSC gibi analitik yöntemlerin yanısıra biyolojik yöntemlerle de karakterize edilmiştir.

BULGULAR: Kitozan-moksifloksazin konjugatları Gram pozitif bakteri Streptococcus pneumoniae ve Staphylococcus aureus gibi çeşitli mikroorganizmalara karşı test edilmiş ve elde edilen sonuçlar kitozan-moksifloksazin konjugatlarının antibakteriyal aktivitelerinin ana ilaç moksifloksazinden birçok kez daha fazla olduğunu göstermiştir. Bu sonuç, ilaç konjugatlarının uygun farmakokinetik, farmakodinamik, mükemmel bakteriyal duyarılılı ve iyi stabilite özelliklerine bağlanabilir.

SONUÇ: Bu önerilen kombinasyon, kitozan ve moksifloksazinin ayrı ayrı aktivitelerinin artırılması ile sonuçlanabilir.

ANAHTAR KELIMELER: MFX (Moksifloksazin), CH (kitozan), konjugat, önilaç, elektrosatik etkileşme, antimikrobiyal vb.

\section{REFERENCES}

1. Bayer. Avelox (moxifloxacin hydrochloride) Tablets Avelox I.V (moxifloxacin hydrochloride in sodium chloride injection). Food and Drug Administration, 2008; 19.

2. Drug watch. Avelox Patent Family. http://www. drugpatentwatch. com/ultimate / preview/tradename/ index.php?query=Avelox. Retrieved 16 September 2012.

3. Drlica K, Zhao X. DNA gyrase, topoisomerase IV, and the 4-quinolones. Microbiol Mol Biol Rev 1997; 61:377-92.

4. Hooper DC. Quinolones. In, Mandell, Douglas, and Bennett's Principles and Practice of Infectious Diseases 2000; 5:404-23.

5. Jayakumar R, Chennazhi KP, Muzzarelli RAA, Tamura H, Nair SV, Selvamurugan N. Chitosan conjugated DNA nanoparticles in gene therapy. Carbohydrate Polymers 2010; 79:1-8.
6. Dev A, Jithin CM, Sreeja V, Tamura H, Patzke GR, Hussain F, Weyeneth S, Nair SV, Jayakumar R. Novel carboxymethyl chitin nanoparticles for cancer drug delivery applications. Carbohydrate Polymers 2010; 79:1073-9.

7. Mathew EM, Jithin CM, Manzoor K, Nair SV, Tamura $\mathrm{H}$, Jayakumar R. Folate conjugated carboxymethyl chitosan-manganese doped zinc sulphide nanoparticles for targeted drug delivery and imaging of cancer cells. Carbohydrate Polymers 2010; 80: 442-8.

8. Khan T, Peh K, Chng H. Mechanical bioadhesive strength and biological evaluations of chitosan films for wound dressing. J Pharm Pharm Sci 2010; 3:303-11.

9. Rabea EI, Badawy ME, Stevens CV, Smagghe G, Steubaut W. Chitosan as antimicrobial agent: applications and mode of action. Biomacromolecules 2003; 4:1457-65. 
10. Wang $X H$, Du YM, Fan LH, Liu H, Hu Y. Chitosanmetal complexes as antimicrobial agent: synthesis and characterization and structure activity study. Polymer Bulletin 2005; 55:105-13.

11. Madhumathi $K$, Sudheesh Kumar PT, Abhilash S, Sreeja V, Tamura H, Manzoor K, Nair SV, Jayakumar R. Development of novel chitin/nanosilver composite scaffolds for wound dressing applications. Journal of Materials Science: Materials in Medicine 2010; 21:807-13.

12. Dutta PK, Tripathi $S$, Mehrotra GK, Dutta J. Perspectives for chitosan based antimicrobial films in food applications. Food Chem 2009;114:1173-82.

13. Peter $M$, Ganesh $N$, Selvamurugan $N$, Nair SV, Furuike $T$, Tamura H, JayakumarR.Preparationand characterization of chitosan gelatin/Nano hydroxyapatite composite scaffolds for tissue engineering applications. Carbohydr Polym 2010;80:687-94.

14. Knill CJ, Kennedy JF, Mistry J, Miraftab M, Smart G, Groocock MR. Alginate fibres modified with unhydrolysed and hydrolysed chitosans for wound dressings. Carbohydr Polym 2004;55:65-76.

15. Kresken M, Wiedemann B. Development of resistance to nalidixic acid and the fluoroquinolones after the introduction of norfloxacin and ofloxacin. Antimicrob Agents Chemother 1988;32:1285-8.
16. Onsoyen E, Skaugrud O. Metal recovery using chitosan. J Chem Technol Biotechnology 1990;49:395-404.

17. Demarger-Andre S, Domard A. Chitosan carboxylic acid salts in solution and in the solid state. Carbohydr Polym 1994; 23:211-9.

18. Anal. Chitosan-alginate multilayer beads for controlled release of ampicillin. Inter J Pharmaceu 2004; 290:45-54.

19. Semwal A, Singh BK, Archana D, Verma A, and Dutta PK. Macromolecular Chitosan-ciprofloxacin pro-drugs: synthesis, physico-chemical and biological assessment for drug delivery systems. J Polym Mater 2012; 29:1-13.

20. Wunderlich B. Macromolecular Physics, Springer 1980;3:8, Table VIII 6.

21. Pungor Erno. A Practical Guide to Instrumental Analysis, Florida: Boca Raton 1995; 181-91.

22. Semwal A, Singh K Brijesh, Archana D, Verma Amita, Dutta PK. Macromolecular chitosan-norfloxacin prodrugs-physiochemical and biological assessment for drug delivery systems. Asain Chitin J 2011; 7:21-8. 